\title{
Leptin induces proliferation and anti- apoptosis in human hepatocarcinoma cells by up-regulating cyclin D1 and down- regulating Bax via a Janus kinase 2-linked pathway
}

\author{
Chiachen Chen ${ }^{1}$, Yuan-Ching Chang ${ }^{2,3}$, Chien-Liang Liü ${ }^{2,3}$, Tsang-Pai Liu ${ }^{2,3}$, \\ King-Jen Chang ${ }^{4}$ and Ing-Cherng Guo ${ }^{1}$
}

\author{
${ }^{1}$ Department of Veterinary Medicine, College of Bio-Resources and Agriculture National Taiwan University, 10617 Taipei, \\ Taiwan ROC \\ ${ }^{2}$ Department of Surgery, Mackay Memorial Hospital, 10449 Taipei, Taiwan ROC \\ ${ }^{3}$ Mackay Medicine, Nursing and Management College, 10449 Taipei, Taiwan ROC \\ ${ }^{4}$ Department of Surgery, National Taiwan University Hospital, National Taiwan University, 10002 Taipei, Taiwan ROC \\ (Requests for offprints should be addressed to I-C Guo; Email: iguo@ntu.edu.tw) \\ $\mathrm{C}$ Chen and $\mathrm{Y}-\mathrm{C}$ Chang contributed equally to this work
}

\begin{abstract}
Obesity serves as an important risk factor for incidences of both cirrhotic and non-cirrhotic hepatocellular carcinoma ( $\mathrm{HCC}$ ), which is the third leading cause of cancer death worldwide. Leptin, the obesity biomarker molecule secreted systemically by body fat mass and locally by activated hepatic stellate cells, is proposed to play a certain role in HCC growth. Here, we show both proliferative and anti-apoptotic effects of leptin in HCC cells. Leptin stimulated cyclin D1 promoter activity to increase cyclin D1 protein expression, which accelerated the cell cycle progression. The reduced ratio between anti-apoptotic (Bcl-2) and pro-apoptotic (Bax) Bcl-2 family proteins by transforming growth factor (TGF)- $\beta 1$ caused HCC cells degradation of poly(ADPribose) polymerase and consequential apoptosis; whereas, leptin protected cells from apoptosis by reversing TGF- $\beta 1$-reduced $\mathrm{Bcl}-2 / \mathrm{Bax}$ ratio as a result of down-regulating Bax. Any inhibitor specific for Janus kinase 2 (JAK2), phosphatidylinositol 3-kinase (PI3K)/Akt, or mitogen-activated protein kinase kinase (MEK)/extracellular signal-regulated kinase 1/2 (ERK1/2) blocked these leptin functions. When intrahepatocytic JAK2 was activated by leptin, the active JAK2 afterward triggered a signaling cascade involving activations of PI3K/Akt and MEK/ERK1/2 in order of occurrence. As yet, in most cases, the crosstalks among signaling pathways primarily studied in diverse cancer cell types for mediating somatotropic effect of leptin are not well clarified and seem to be cell-type dependent. For the first time, our results demonstrate the direct effects of leptin on HCC growth and define its signal pathway with a crosstalking JAK2-PI3K/Akt-MEK/ERK1/2 connection. The identified hierarchy of intrahepatocytic leptin signaling pathway provides a clear basis potentially beneficial to make accurate and effectual strategies for facing both cirrhotic and non-cirrhotic liver carcinogenesis.
\end{abstract}

Endocrine-Related Cancer (2007) 14 513-529

\section{Introduction}

Obesity and related metabolic consequences bear close relation to the initiation and progression of cancers developing from various tissues, such as breast, ovary, endometrium, cervix, prostate, esophagus, stomach, pancreas, colon and rectum, liver, kidney, gallbladder, non-Hodgkin's lymphoma, and multiple myeloma (Calle et al. 2003, Jackson 2005, Uauy \& Solomons 2005). Nevertheless, the mechanism underlying the obesity-increased risk of liver cancer is not yet clear. 
The increased prevalence of obesity was accompanied with the elevated incidence of hepatocellular carcinoma (HCC; Dyer et al. 2005). The obesity-associated metabolic syndrome probably leads to the development of HCC from fatty liver through the progression of alcoholic or non-alcoholic steatohepatitis, fibrosis, and cirrhosis. Compared with patients with alcohol- or virus-associated cirrhotic HCC, the cirrhotic HCC patients of unknown etiology had higher prevalence of obesity (Bugianesi et al. 2002, Regimbeau et al. 2004), suggesting that obesity is possibly involved in the development of HCC from cryptogenic cirrhosis. In addition to increasing the alcohol- or tobacco-induced risk of cirrhotic HCC, obesity also increased 48- and 4-fold risks of cirrhotic HCC compared with non-obese normal controls and non-obese cirrhotic controls respectively (Marrero et al. 2005). These observations indicate that obesity perhaps serves as both independent and synergistic risk factors of cirrhotic HCC. Moreover, obesity may also promote cirrhosis-independent hepatic carcinogenesis. Ten cases of noncirrhotic HCC arising in obese patients were recently reported; noticeably, all were free from the infection of hepatitis $\mathrm{B}$ virus or hepatitis $\mathrm{C}$ virus and showed normal values in almost all of liver function tests, except seven cases of them with mild elevation of $\gamma$-glutamyl transferase (Gonzalez et al. 2004). It appears that certain factors derived from adipose tissues plausibly play positive roles in liver tumorigenesis.

Leptin, the major adipocyte-derived adipocytokine, is a known biomarker molecule of obesity due to the tight association of its circulating levels with body mass index and total body fat (van Gaal et al. 1999). At least, six transcript variants of leptin receptors (OBRs), which belong to class I cytokine receptor family, were identified and designed as OBRa-f (Fruhbeck 2006). Without an intrinsic tyrosine kinase activity, the liganded OBR usually activates a cytoplasmic kinase, Janus kinase 2 (JAK2), to transmit leptin signals intracellularly (Fruhbeck 2006). The expressions of OBRs variants had been detected in human normal hepatocytes (Briscoe et al. 2001), HCC cell lines (Cohen et al. 1996, Wang et al. 1997, Liu et al. 2004), as well as in human HCC tissues and their surrounding non-tumoral liver tissues (Wang et al. 2004). These studies indicated that both human non-malignant and malignant hepatocytes are capable of directly receiving leptin signaling. The responsiveness of human hepatocytes to physiological levels of leptin, primarily secreted by subcutaneous and abdominal adipose tissues, has been demonstrated (Chen et al. 2006b). Interestingly, leptin could be produced by HCC and normal liver tissues (Wang et al. 2004), as well as activated hepatic stellate cells (HSCs; Ding et al. 2005), possibly leading to the high accumulation of intrahepatic leptin; therefore, leptin signaling perhaps controls the growth of hepatocytes and HCC cells via endocrine, paracrine, and/or autocrine modes.

Actually, the growth factor-like functions of leptin had been observed in many types of cancer cells (Somasundar et al. 2004, Garofalo \& Surmacz 2006). Given that JAK2-initiated signaling pathways, such as phosphatidylinositol 3-kinase (PI3K)/protein kinase B (Akt) and mitogen-activated protein kinase kinase (MEK)/extracellular signal-regulated kinase $1 / 2$ (ERK1/2) had been revealed to mediate proliferative and/or anti-apoptotic effects of leptin in various cancer cell types, such as breast (Chen et al. 2006a, Frankenberry et al. 2006), endometrium (Sharma et al. 2006), and neuroblastoma (Russo et al. 2004), we hypothesize that leptin might also have a somatotropic function in HCC cells possibly by activating JAK2-linked PI3K/Akt and MEK/ERK1/2 pathways. Although only one paper, to the best of our knowledge, had reported the proliferative effect of leptin on non-tumoral hepatic WRL-68 cells (Briscoe et al. 2001), no publication describes the somatotropic effect of leptin in HCC cells. In this paper, we are intended to verify the proliferative and anti-apoptotic effects of leptin and study the underlying mechanisms along with their signaling pathways in HCC cells. Here, we demonstrate that leptin directly stimulates proliferation and inhibits transforming growth factor (TGF)- $\beta 1$-induced apoptosis of HCC cells. Our evidence show that leptin up-regulates cyclin D1 to speed up cell cycle progression and down-regulates Bax to reduce programed cell death. These leptin effects are plausibly mediated by JAK2-initiated signaling pathway that involves activations of PI3K/ Akt and MEK/ERK1/2 in order of occurrence.

\section{Materials and methods}

\section{Reagents and antibodies}

Human recombinant leptin, epidermal growth factor (EGF), tyrphostin AG490, U0126, wortmannin, LY294002, PD98059, monoclonal anti- $\beta$-actin antibody (Sigma Chemical Co.), TGF- $\beta$ (R\&D Systems Inc., Minneapolis, MN, USA), polyclonal antibodies against phospho-JAK2 (Upstate, Charlottesville, VA, USA), Bax, PARP, phospho-Akt, or phospho-ERK1/2 (Cell Signaling Technology, Beverly, MA, USA), JAK2 or ERK1/2 (Santa Cruz Biotechnology Inc., Santa Cruz, CA, USA), and 
monoclonal antibody against Akt, Bcl-2, or cyclin D1 (BD Pharmingen, Palo Alto, CA, USA) were commercially obtained.

\section{Cell lines and culture}

The human HCC cell lines, Hep3B and HepG2, as well as non-malignant hepatic cell line, Chang liver, were obtained from the American Type Culture Collection and cultured in Dulbecco's modified Eagle medium (Invitrogen Co.) supplemented with $10 \%$ fetal calf serum (Biological Industries Ltd, Kibbutz Beit Haemek, Israel), $100 \mathrm{U} / \mathrm{ml}$ penicillin $\mathrm{G}$, and $0.1 \mathrm{~g} / \mathrm{l}$ streptomycin (Sigma Chemical Co.) in a $5 \% \mathrm{CO}_{2}$ incubator at $37^{\circ} \mathrm{C}$.

\section{RT-PCR}

Total cellular RNA was extracted with Trizol reagent (Invitrogen Co). The RT-PCR was performed with the published protocol (Chen et al. 2006a, Hsu et al. 2006). Briefly, $2 \mu \mathrm{g}$ total RNA were denatured at $65^{\circ} \mathrm{C}$ for $20 \mathrm{~min}$, immediately cooled on ice, and incubated with the reverse transcriptase reaction mixture (1 U RNase inhibitor, $1 \mathrm{mM}$ dNTP, $1 \mu \mathrm{M}$ poly-dT oligonucleotide; Roche Applied Science), and 0.4 U MMLV reverse transcriptase (Invitrogen Co.) in a total volume of $20 \mu \mathrm{l}$ at $37^{\circ} \mathrm{C}$ for $90 \mathrm{~min}$ to generate the first-strand cDNA. Following stopped by $95^{\circ} \mathrm{C}$ for $5 \mathrm{~min}$ and rapidly cooled on ice, the reversely transcribed cDNA was further PCR-amplified by specific primers in $50 \mu \mathrm{l}$ PCR mixture (cDNA, $0.25 \mathrm{mM}$ dNTP, $1 \mu \mathrm{M}$ forward and reverse primers, $0.5 \mathrm{U}$ Taq). The paired primer sets included forward OBRb (5'-CCA GAA ACG TTT GAG CAT CT$\left.3^{\prime}\right)$ and reverse OBRb (5'-CAA AAG CAC ACC ACT CTC TC-3'), or forward OBRa (5'-GAA GGA GTG GGA AAA CCA AAG- $\left.3^{\prime}\right)$ and reverse OBRa (5'-CCA CCAT ATG TTA ACT CTC AG-3').

\section{MTT assay}

After cells were seeded in 96-well plates, serum starved for $24 \mathrm{~h}$, and then incubated with indicated reagent in serum-free media for $48 \mathrm{~h}$, the cell viabilities were measured using the 3-(4,5-dimethylthiazolyl)-2,5diphenyl tetrazolium bromide (MTT) proliferation assay with the previous protocol (Chen et al. 2006a). In brief, after cells were collected and incubated in medium containing $2 \mathrm{mg} / \mathrm{ml}$ MTT reagent (Sigma Chemical Co.) at $37{ }^{\circ} \mathrm{C}$ for $4 \mathrm{~h}$, the formazan crystals converted from tetrazolium salts by viable cells were dissolved in dimethyl sulfoxide $(150 \mu \mathrm{l} /$ well $)$ and their absorbance at $570 \mathrm{~nm}$ was measured by a microplate spectrophotometer to reflect cell viability.

\section{Cell number counting}

After seeded in six-well plates and treated with vehicle or $250 \mathrm{ng} / \mathrm{ml}$ recombinant human leptin, the cells were harvested at the indicated time points and stained with 0.5\% Trypan blue (Biological Industries). Subsequently, the number of viable cells was counted under a light microscope (Chen et al. 2006a).

\section{Flow cytometry}

The previous protocol for flow cytometric analysis was followed (Chen et al. 2006a). Briefly, cells were starved in serum-free media for 1 day followed by treatment with indicated reagent. After $48 \mathrm{~h}$, cells were trypsinized, washed twice with cold PBS, and fixed in $70 \%$ ethanol at $-20{ }^{\circ} \mathrm{C}$ for permeabilization. After $18 \mathrm{~h}$, cells were washed and resuspended in PBS containing RNase $(0.01 \mathrm{mg} / \mathrm{ml})$ and propidium iodide $(50 \mu \mathrm{g} / \mathrm{ml}$; Sigma Chemical Co. $)$ at $37{ }^{\circ} \mathrm{C}$ for $30 \mathrm{~min}$. The cell cycle profile was determined by Becton Dickinson FACScan, and the data were analyzed with ModFit LT 3.1 (Becton Dickinson, St José, CA, USA).

\section{Construction of pCD-1KLuc plasmid}

The cyclin D1 promoter fragment from -927 to +39 bp was PCR amplified using restriction enzyme site-tailed-specific primers designed by ourselves according to the sequences deposited in the GenBank (Accession no. Z29078) and genomic DNA extracted from normal human leukocytes, and then inserted in front of the firefly luciferase reporter gene contained in a promoterless pGL3Basic vector (Promega Co.) to generate the $\mathrm{pCD}-1 \mathrm{KLuc}$ construct. The used primers were CD/SacI-927 (5'-GTC GAG CTC AGC TTT CCA TTC AGA-3') and CD/HindIII +39 (5'-ACA AAG CTT CTG CTG CTC GCT GCT A-3').

\section{Transfection and luciferase activity assay}

After 1-day serum deprivation, plasmids of pCD1KLuc or pGL3Basic, together with pRluc-C1 (Perkin-Elmer Life Sciences, Boston, MA, USA), a CMV promoter-driven renilla luciferase construct as an internal control, were co-transfected into Hep3B with Lipofectamine Plus (Invitrogen Co.) according to manufacturer's instruction in 24-well plates, and then maintained in serum-free media. After $24 \mathrm{~h}$, pGL3Basic-transfected cells (pGL3) were still maintained in serum-free media, but pCD-1KLuc-transfected cells were incubated with serum-free media containing indicated reagent. After 48-h treatment, the transfected cell extracts were harvested and subjected to the dual luminescence reporter gene assay system 
(Perkin-Elmer Life Sciences) with the manufacturer's instruction for detecting their luciferase activities. The relative luciferase activities were calculated by normalizing firefly luciferase activities with renilla luciferase activities.

\section{Western blotting analysis}

The protocol for western blotting was modified from the previous publication (Guo et al. 2001). Briefly, cell lysates were extracted with the lysis buffer $(10 \mathrm{mM}$ Tris- $\mathrm{HCl}$ (pH 7.5), $150 \mathrm{mM} \mathrm{NaCl}, 10 \%$ glycerol, $1 \%$ Triton X-100, $1 \mathrm{mM}$ dithiothreitol, $0.2 \mathrm{mM}$ phenylmethylsulphonyl fluoride, $1 \mu \mathrm{g} / \mathrm{ml}$ aproptinin, $1 \mu \mathrm{g} / \mathrm{ml}$ leupeptin, $1 \mathrm{mM} \mathrm{Na} \mathrm{VO}_{4}$, and $1 \mathrm{mM} \mathrm{NaF}$ ) and separated on $12 \%$ SDS-PAGE gel. After the electrophoresed proteins were electrotransferred onto the nitrocellulose membrane (Perkin-Elmer Life Sciences), the membrane was blocked with $5 \%$ skim milk in TBST (20 mM Tris- $\mathrm{HCl}(\mathrm{pH} 7.6), 137 \mathrm{mM}$ $\mathrm{NaCl}$, and $0.1 \%$ Tween-20), probed with appropriate primary antibodies at $4{ }^{\circ} \mathrm{C}$ overnight and bound with HRP-conjugated secondary antibodies (Jackson ImmunoResearch Laboratories Inc., West Grove, PA, USA) at room temperature for $1 \mathrm{~h}$. After reacted with a chemiluminescence substrate (Amersham Biosciences), the blot was autographed onto an X-ray film (Fuji Photo Film Co., Ltd., Tokyo, Japan).

\section{Statistical analysis}

Statistical analyses were calculated with Student's $t$-test. All data are presented as the mean \pm s.D. and statistically significant difference is indictated in figures and tables with the description in the figure legend.

\section{Results}

\section{Hepatic malignant and non-malignant cell lines express leptin receptors}

The expressions of two major isoforms of leptin receptors, the long-form $\mathrm{OBRb}$ and the short-form OBRa, had been detected in cells of liver origin (Cohen et al. 1996, Wang et al. 1997, Briscoe et al. 2001, Liu et al. 2004). We confirmed mRNA expressions of $\mathrm{OBRb}$ and OBRa in human malignant HCC cell lines, Hep3B and HepG2, as well as non-malignant Chang liver cell line with RT-PCR (Fig. 1A), suggesting that hepatic malignant and non-malignant cell lines are capable of receiving leptin signals, at least partly, via these two OBRs.

\section{Leptin promotes cell cycle progression to stimulate growth of hepatic cells}

Leptin functions as a growth factor in variety of cell types (Somasundar et al. 2004, Garofalo \& Surmacz 2006), thus, we tested leptin effect on growth of Hep3B, HepG2, and Chang liver cells. The results from MTT assay and Trypan blue staining method, both of which were used to indirectly and directly respectively, determine the cell viability, and were expected to reflect the regulation of cell growth by leptin. The results of MTT assays showed a dose-dependent stimulation of cell growth by 48 -h leptin treatment. The significant stimulation was observed from the dose as low as $31.25 \mathrm{ng} / \mathrm{ml}$ in Hep3B (Fig. 1B) and HepG2 (Fig. 1C), but the higher dose up to $62.5 \mathrm{ng} / \mathrm{ml}$ in Chang liver (Fig. 1D). The leptin effect was doubly checked with Trypan blue staining for directly counting the viable cell number. The significant increment of cell number was observed over 3-day leptin treatment in Hep3B (Fig. 1E) and Chang liver (Fig. 1F). These results indicate that leptin exerts growth-stimulating effect on both hepatic malignant and non-malignant cells.

To understand whether leptin has any survival effect to sustain higher cell number in condition of serum starvation, Hep3B was pre-incubated (on day -1) in serum-free medium for 1 day before treatment (from days -1 to 0 ), and then treated with leptin or vehicle (control; on day 0) in serum-free medium for two days (from days 0 to 2). As shown in Fig. 1G, 2-day serum deprivation (from days -1 to 1 ) did not cease the elevation of cell number in both leptin-treated and control groups; however, cell number of the leptintreated group was significantly higher than that of the control group, presumably due to proliferative effect of leptin in majority. On the subsequent day 2, cell number of the control group fell down that implies cells are dying after 3-day serum deprivation; on the contrary, the leptin-treated group maintained cell number at the same level as that on day 1. Most likely, in addition to proliferative effect, the survival effect of leptin may also be involved in the maintenance of cell number over 3-day serum deprivation.

Furthermore, we like to verify the proliferative effect of leptin. We evaluated the fate of leptin-treated Hep3B cells within the cell cycle. Cells were synchronized with 24-h serum starvation and then induced to re-enter the cell cycle by treatment with leptin. Flow cytometric analysis was performed after propidium iodide staining. After 2-day treatment, leptin significantly reduced the proportion of G0/G1phase cell populations, but increased the number of 
A
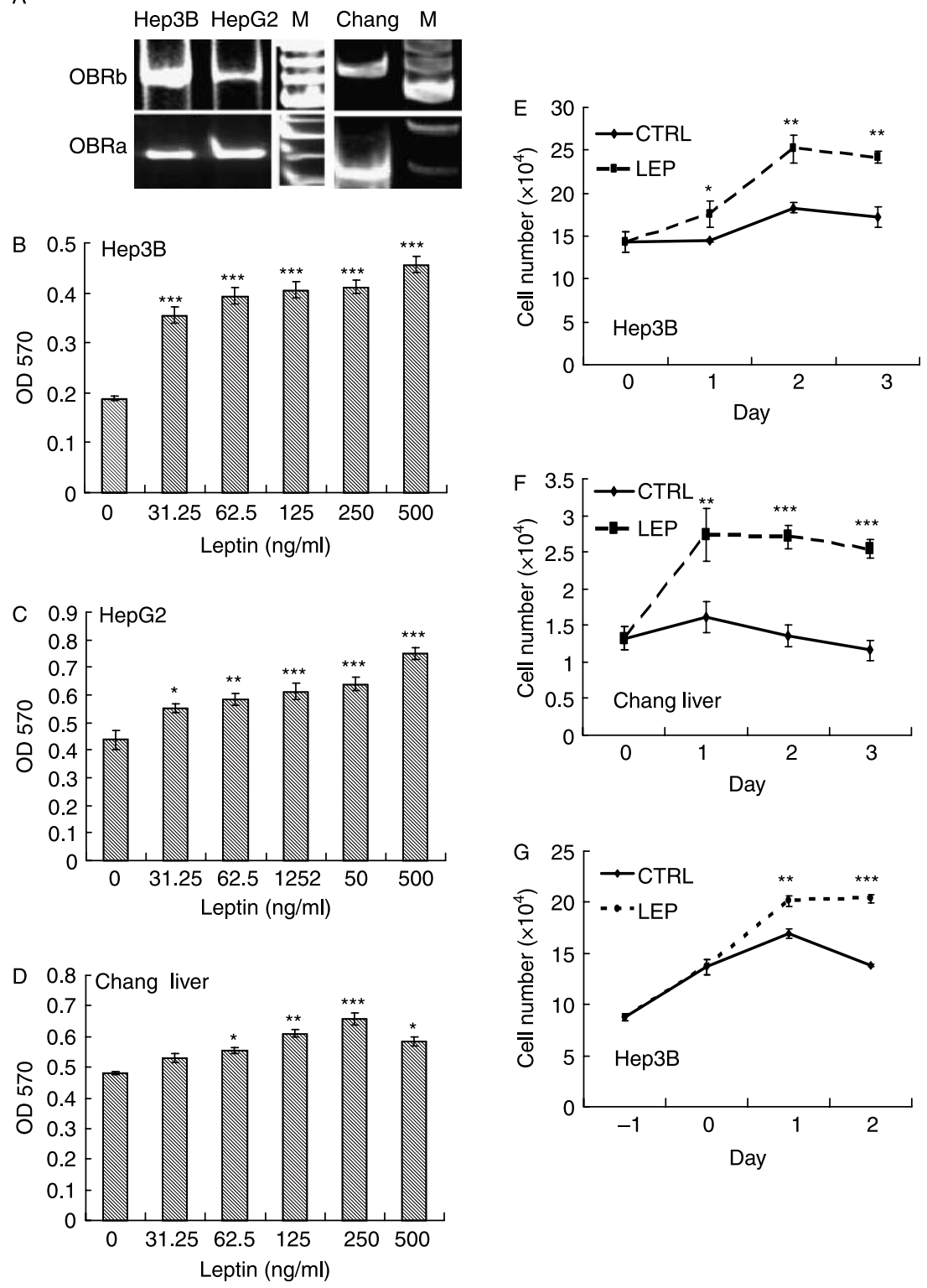

Figure 1 Leptin stimulates hepatic cell growth. The mRNA expressions of OBRb and OBRa were detected in human hepatic malignant (A) Hep3B, HepG2, and non-malignant Chang liver cell lines with RT-PCR. The amplified cDNA fragments, 609 bp $\mathrm{OBRb}$ and $364 \mathrm{bp}$ OBRa, together with DNA marker (M) were electrophoresed. Hepatic malignant Hep3B, HepG2, and nonmalignant Chang liver cell lines are capable of receiving leptin signal, at least partly, through OBRb and OBRa. After (B) Hep3B, (C) HepG2, and (D) Chang liver were seeded in 96-well plates, serum starved for $24 \mathrm{~h}$, and then incubated with serial doses of leptin as indicated in serum-free media for $48 \mathrm{~h}$, the cell viabilities were measured using MTT assay. The cell number of $(E)$ Hep3B and $(F)$ Chang liver maintained in serum-free media containing $250 \mathrm{ng} / \mathrm{ml}$ leptin (LEP) or vehicle (CTRL) for indicated days was determined by Trypan blue staining. Leptin stimulates growth of malignant and non-malignant hepatic cell lines in dose- and time-dependent manners. To further compare the cell viabilities before and after leptin treatment, Hep3B cells seeded in six-well plates were serum starved before treatment (day -1$)$, and 1 day later treated with $250 \mathrm{ng} / \mathrm{ml}$ leptin (LEP) or vehicle (CTRL) in serum-free media over 2 days (G). The cell number was counted by Trypan blue staining every $24 \mathrm{~h}$ from days -1 to 2 . Leptin appears to proffer both proliferative and survival effects for maintaining the cell number of serum-starved Hep3B. The mean and S.D. values were calculated from 24 replicates for MTT assay and triplicates for cell counting. The statistically significant differences compared with the control are noted as ${ }^{*} P<0.05$, ${ }^{\star *} P<0.01$, and ${ }^{* * *} P<0.001$. Data represent three independent experiments. 
both S- and G2/M-phase cells, in a dose-dependent fashion $(62.5-250 \mathrm{ng} / \mathrm{ml}$; Table 1). These results suggest that leptin promotes cell cycle progression to stimulate growth of HCC cells.

\section{Leptin induces cyclin D1 expression}

Cyclin D1 is a growth sensor induced by growth factors and mitogens to accelerate G1 progression (Knudsen et al. 2006); therefore, we examined leptin effect on cyclin D1 expression. In Hep3B, the amounts of cyclin D1 protein, detected with western blotting analysis, were gradually increased by increasing doses of leptin (Fig. 2A). To understand if leptin controls cyclin Dl gene expression, we analyzed cyclin D1 promoter activity in response to leptin treatment. The luciferase activity of Hep3B transfected with pCD-1KLuc, a pGL3Basic backbone construct containing a reporter luciferase gene driven by $5^{\prime}$-flanking $-927 /+39$ region of cyclin $D 1$ gene, in leptin-treated group was significantly higher than that in control group, and the comparable activity was observed in the group treated with EGF or $5 \%$ fetal calf serum, which supposedly contains a variety of growth factors (Fig. 2B). The parent vector pGL3Basic expressed background levels due to lack of promoter (Fig. 2B). These results suggest that leptin, like growth factors, up-regulates cyclin $D 1$ gene expression, by which the hepatic cell cycle progression may be accelerated.

\section{Leptin stimulates cell growth through activations of JAK2, PI3K/Akt, and MEK/ERK1/2}

The JAK2/signal transducer and activator of transcription 3 (STAT3), PI3K/Akt, and MEK/ERK1/2 pathways mostly mediate intracellular leptin signaling in various cell types (Fruhbeck 2006); accordingly, we investigated their roles in the leptin-stimulated growth of hepatic cells. As measured with western blotting analyses, although the total protein amounts of JAK2, Akt, and ERK1/2 were quite refractory to leptin, their phosphorylated forms were dose-dependently induced by leptin in Hep3B (Fig. 3A) and Chang liver (Fig. 3B).

Table 1 Leptin promotes cell cycle progression in Hep3B cells

\begin{tabular}{lccc}
\hline $\begin{array}{l}\text { Leptin } \\
\text { (ng/ml) }\end{array}$ & \% G0/G1-phase & $\%$ S-phase & \% G2/M-phase \\
\hline 0 & $88.0 \pm 1.1$ & $5.4 \pm 0.7$ & $6.7 \pm 0.4$ \\
62.5 & $83.4 \pm 1.8^{\star}$ & $6.4 \pm 0.9$ & $10.2 \pm 0.9^{\dagger}$ \\
125 & $80.8 \pm 2.2^{\dagger}$ & $9.1 \pm 1.4^{\dagger}$ & $10.1 \pm 0.7^{\dagger}$ \\
250 & $74.4 \pm 1.9^{\ddagger}$ & $7.6 \pm 0.7^{\dagger}$ & $18.3 \pm 0.3^{\ddagger}$ \\
\hline
\end{tabular}

${ }^{\star} P<0.05,{ }^{\dagger} P<0.01$, and ${ }^{\ddagger} P<0.001$ versus the control $(0 \mathrm{ng} / \mathrm{ml})$.
A

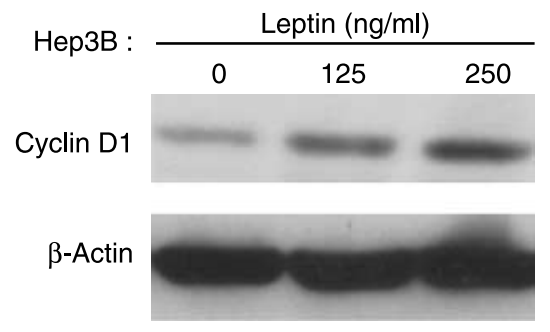

B

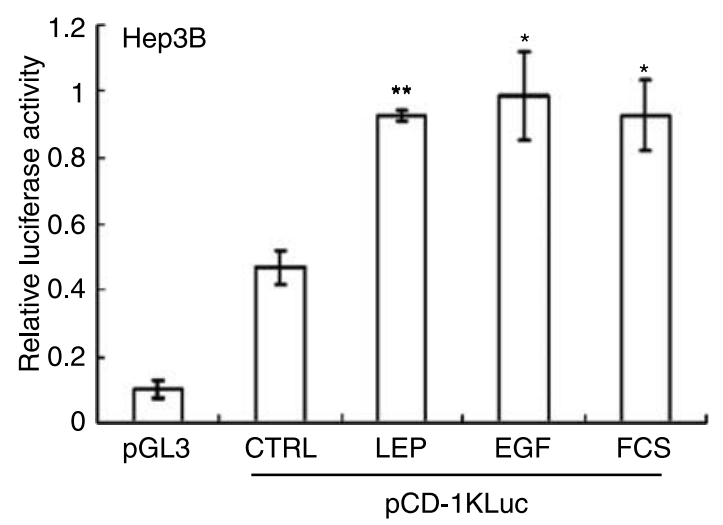

Figure 2 Leptin induces hepatic cyclin D1 expression. After 1day serum deprivation, Hep3B cells were incubated in serumfree media containing indicated concentration of leptin for $48 \mathrm{~h}$, and then the amounts of cyclin D1 protein were detected with western blotting analysis using $\beta$-actin as an internal control $(A)$. As well, after 1-day serum deprivation, Hep3B was transfected with $\mathrm{pCD}-1 \mathrm{KLuc}$ containing a firefly luciferase gene driven by the $-927 /+39$ fragment of cyclin D1 promoter, or the promoterless parent vector, pGL3Basic (pGL3) as a negative control, together with a CMV promoter-driven renilla luciferase construct as an internal control, and then maintained in serumfree media. After $24 \mathrm{~h}$, pGL3Basic-transfected cells (pGL3) were still maintained in serum-free media, but pCD-1KLuctransfected cells were incubated with serum-free media containing vehicle (CTRL), $250 \mathrm{ng} / \mathrm{ml}$ leptin (LEP), $40 \mathrm{ng} / \mathrm{ml}$ EGF, or $5 \%$ fetal calf serum (FCS) (B). After 48-h treatment, the transfected cell extracts were harvested and subjected to the dual luminescence reporter gene assay system for detecting their luciferase activities. After normalization of firefly luciferase activities with renilla luciferase activities, the relative luciferase activities calculated from triplicates were graphed with the mean \pm s.D. values. Similar results were observed in three independent experiments. The statistically significant differences compared with the control (CTRL) are noted as ${ }^{\star} P<$ $0.05,{ }^{\star \star} P<0.01$, and ${ }^{\star \star \star} P<0.001$. Comparable with EGF and serum, leptin stimulates cylin $D 1$ gene expression of HCC cells.

Simultaneously, the time-course experiments showed that the levels of phosphorylated forms of JAK2, Akt, and ERK1/2 were increased as soon as $10 \mathrm{~min}$ in Hep3B (Fig. 3C) and 5 min in Chang liver (Fig. 3D) during leptin treatment. These results identify the activations of JAK2, Akt, and ERK1/2 signaling kinases by leptin in hepatic cells. 


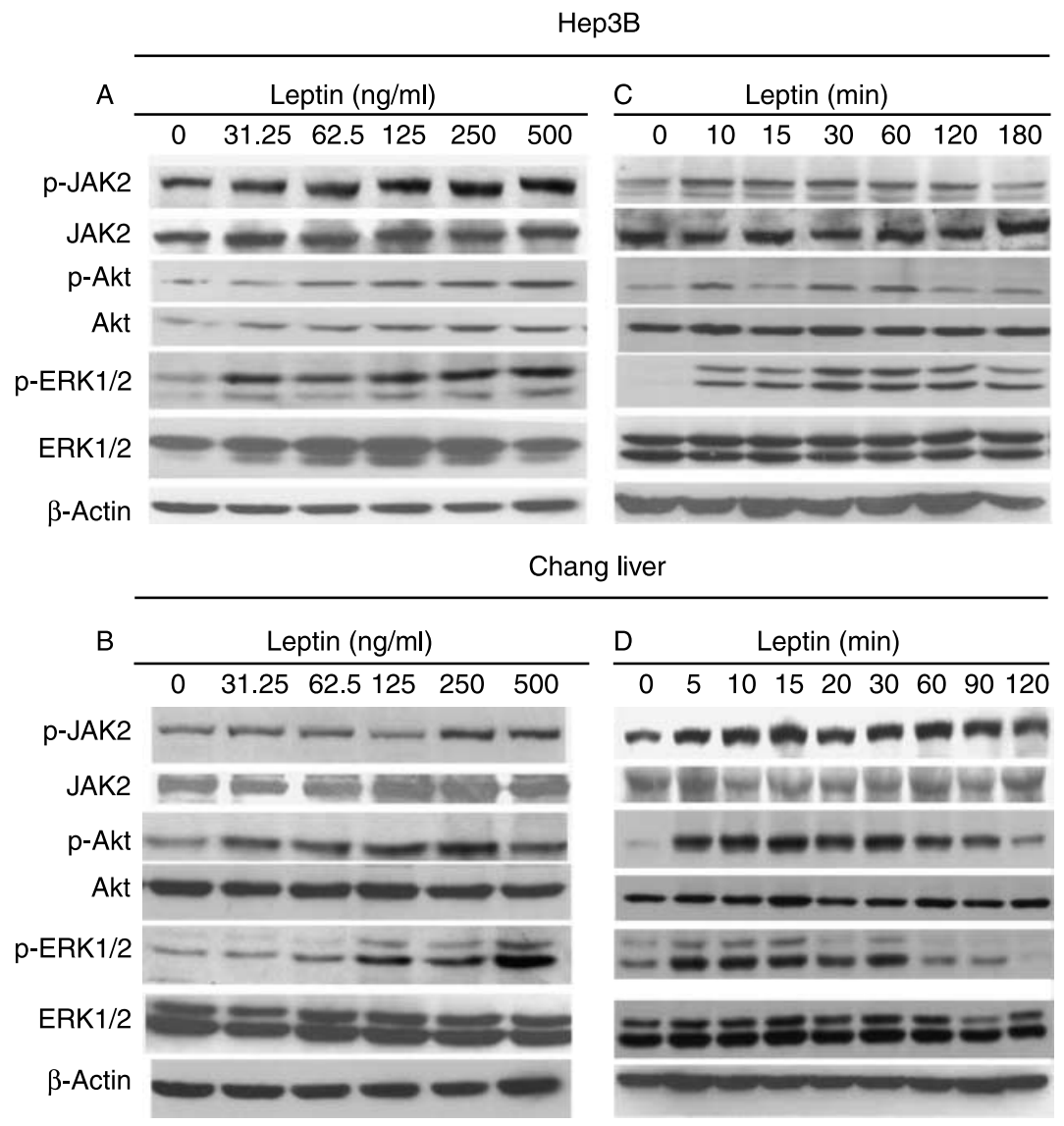

Figure 3 Leptin activates phosphorylations of JAK2, Akt, and ERK1/2 in hepatic cells. After 1-day serum deprivation, leptin was added into the serum-free medium of Hep3B for $30 \mathrm{~min}(\mathrm{~A})$ or Chang liver for $15 \mathrm{~min}(\mathrm{~B})$ with the increasing concentrations as indicated, and then the protein amounts of phosphorylated forms of JAK2 (p-JAK2), Akt ( $p$-Akt), or ERK1/2 ( $p$-ERK1/2) were detected with western blotting analyses. The same blots were stripped and reprobed with antibodies specific for total proteins of JAK2, Akt, or ERK1/2. Similar western blotting analyses were carried out with the cell lysates of (C) Hep3B and (D) Chang liver treated with $250 \mathrm{ng} / \mathrm{ml}$ leptin for the indicated time-courses. Data represent three independent experiments. The reprobed $\beta$-actin was used as an alternative internal control. Leptin acutely and dose-dependently induces activations of JAK2, Akt, and ERK1/2 in human malignant and non-malignant hepatocytes.

Next, we used pharmacological inhibitors to determine the involvement of these signaling kinases in the growth-stimulating effect of leptin. The results from MTT assays showed that the leptin-stimulated cell growth of Hep3B was blocked by the inhibitor specific for JAK2 (AG490; Fig. 4A), PI3K (wortmannin; Fig. 4B), or MEK1/2 (U0126; Fig. 4C). Similar results were seen in Chang liver (Fig. 4D-F). To avoid that the unspecific or unexpected effects of above-mentioned inhibitors misled the results of inhibition experiments, the inhibition experiments were also carried out with analogous pharmacological inhibitors. Similar to wortmannin and U0126, the PI3K inhibitor, LY294002 (Fig. 4G), and the MEK1/2 inhibitor, PD98059 (Fig. 4H) respectively, blocked the leptin-induced Hep3B cell growth. Taken together, these findings consistently reveal that leptin possibly activates the signaling pathways, including JAK2, PI3K/Akt, and MEK/ERK1/2 to stimulate growth of both hepatic malignant and non-malignant cells.

\section{Leptin activates signaling crosstalks among JAK2, PI3K/Akt, and MEK/ERK1/2}

The reports describing the linkage among JAK2, PI3K/Akt, and MEK/ERK1/2 pathways (Zhao et al. 2000, 2002, Menu et al. 2004, Sahu 2004, Pai et al. 2005) reminded us to inspect whether there is any connection among these signaling pathways to mediate leptin effect. With western blotting analyses, we observed that leptin effectively induced the levels of phosphorylated forms of JAK2, Akt, and ERK1/2 with little influence on their total protein amounts in both Hep3B (Fig. 5A, lanes 1 and 2) and Chang liver (Fig. 5B, lanes 1 and 2). As expected, pre-treatment with AG490, U0126, and wortmannin 

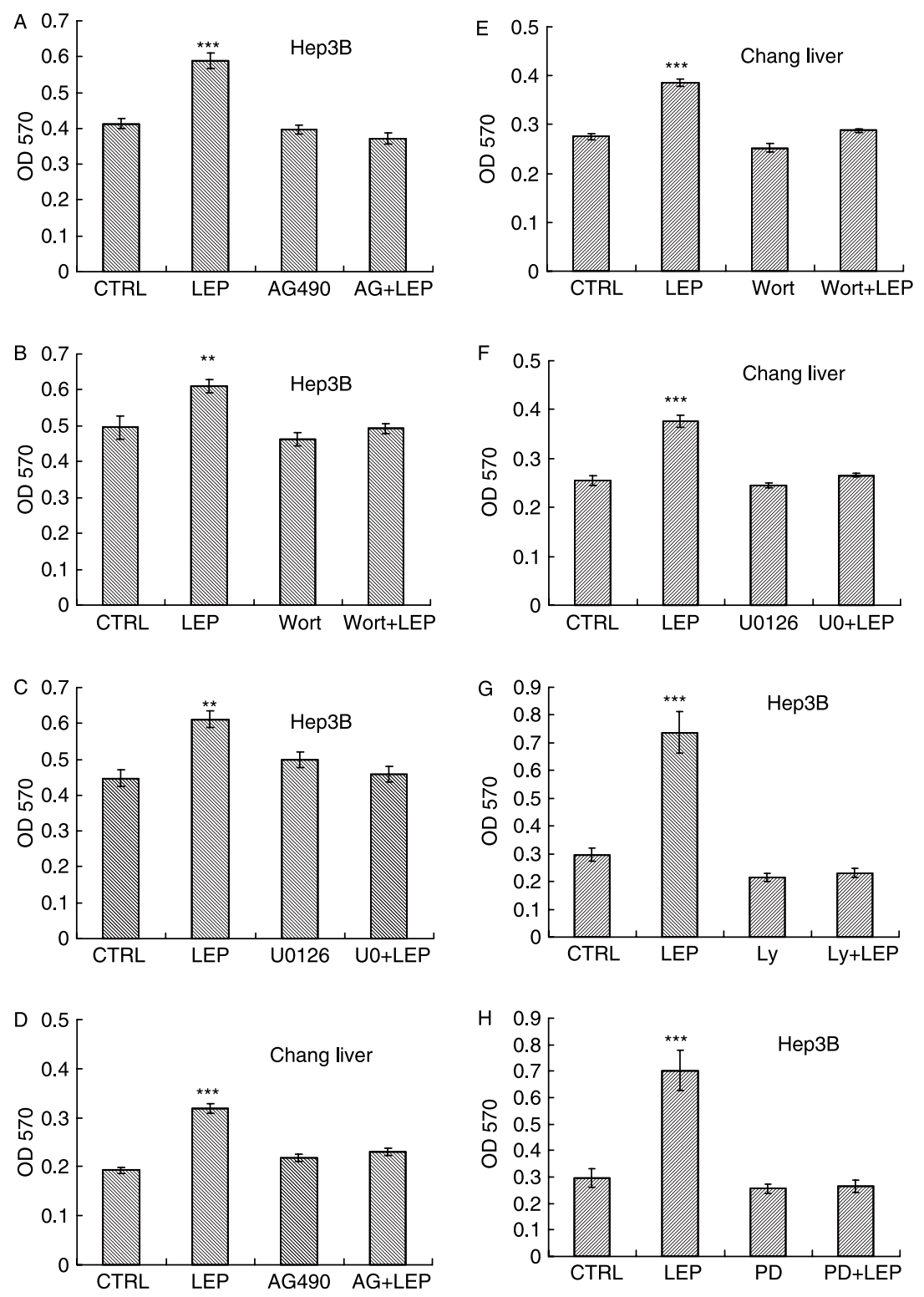

Figure 4 Pharmacological inhibitors of JAK2, PI3K/Akt, and MEK/ERK1/2 prevent hepatic cell growth from leptin induction. After 1day serum deprivation, (A-C) Hep3B and (D-F) Chang liver were treated with vehicle (CTRL), $250 \mathrm{ng} / \mathrm{ml} \mathrm{leptin}$ (LEP), $40 \mu \mathrm{M}$ AG490 (AG), $250 \mathrm{nM}$ wortmannin (Wort), $10 \mu \mathrm{M}$ U0126 (U0), or $250 \mathrm{ng} / \mathrm{ml}$ leptin together with $40 \mu \mathrm{M}$ AG490 (AG + LEP), $250 \mathrm{nM}$ wortmannin (Wort + LEP), or $10 \mu \mathrm{M}$ U0126 (U0 + LEP) in serum-free media for $48 \mathrm{~h}$, and then cell viabilities were measured with MTT assay. To doubly check the specificity of kinase inhibition, similar experiments were carried out with (G) $25 \mu \mathrm{M}$ LY294002 (Ly) and $(\mathrm{H}) 20 \mu \mathrm{M}$ PD98059 (PD) replacing wortmannin and U0126 respectively, in Hep3B. The mean and s.D. values were calculated from 24 replicates. The statistically significant differences compared with the control (CTRL) are noted as ${ }^{\star} P<0.05$, ${ }^{\star \star} P<0.01$, and ${ }^{* \star \star} P<0.001$. Similar results were obtained from three independent experiments. Activations of JAK2, PI3K/Akt, and MEK/ERK1/2 mediate leptin induction on growth of human malignant and non-malignant hepatocytes.

specifically disabled leptin for inducing phosphorylations of JAK2, ERK1/2, and Akt respectively (Fig. 5A and B, lanes 3-5). Furthermore, the JAK2-specific inhibitor AG490 concurrently prevented leptin-induced phosphorylations of JAK2, Akt, and ERK1/2 (Fig. 5A and $\mathrm{B}$, lane 3), but the inhibitors specific for MEK/ERK1/ 2 (U0126) and PI3K/Akt (wortmannin) did not affect leptin-induced phosphorylation of JAK2 (Fig. 5A and B, lanes 4 and 5). These results indicate that JAK2 plays as an upstream mediator of both PI3K/Akt and MEK/ ERK1/2 in intrahepatocytic leptin signaling. In addition, U0126 prohibited leptin-induced phosphorylation of ERK1/2 without influence on leptin-induced phosphorylation of Akt (Fig. 5A and B, lane 4), but wortmannin 
A

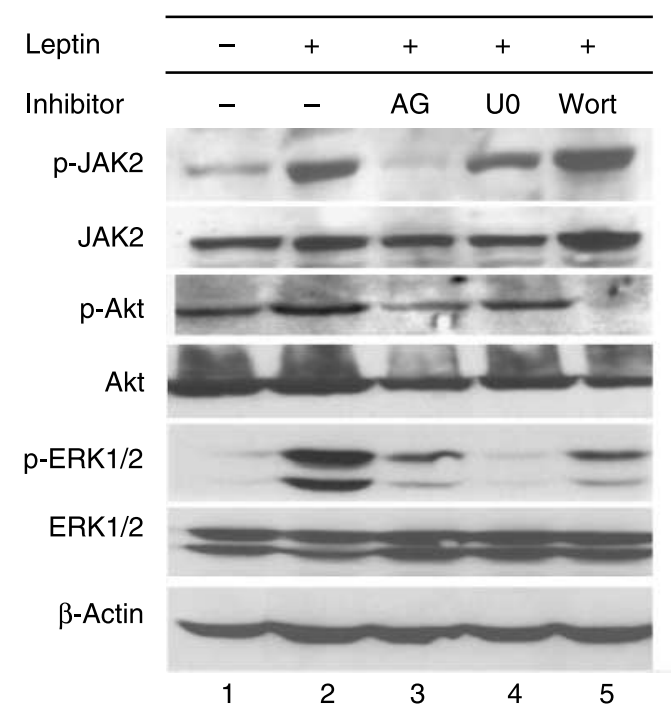

C

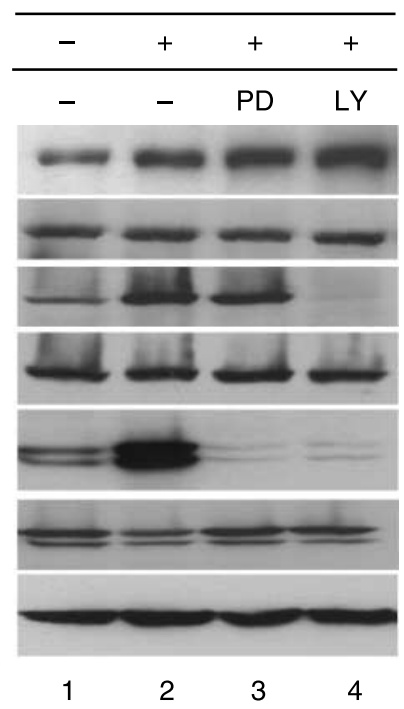

B

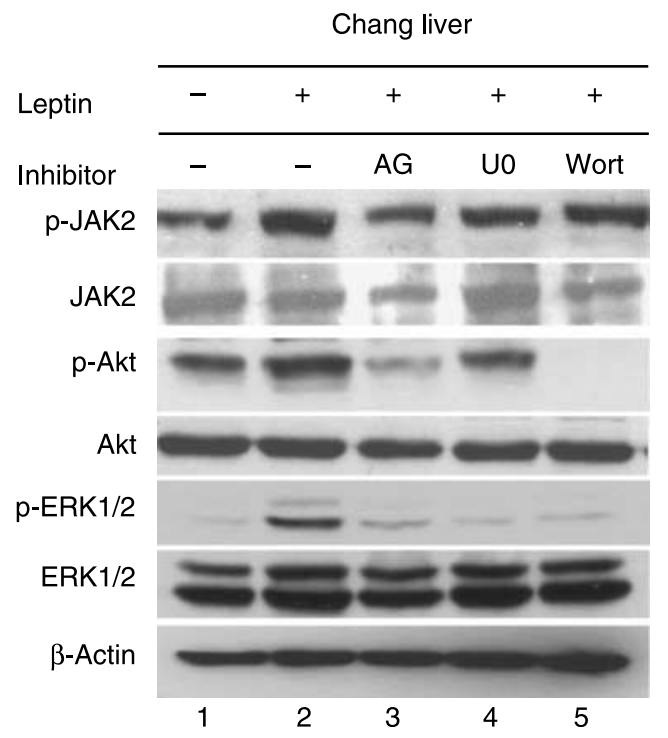

Figure 5 Leptin triggers JAK2-linked PI3K/Akt and MEK/ERK1/2 signaling pathways. After 1-day serum deprivation and then 30-min pre-treatment of vehicle (-), $40 \mu \mathrm{M}$ AG490 (AG), $250 \mathrm{nM}$ wortmannin (Wort), or $10 \mu \mathrm{M}$ U0126 (U0), (A) Hep3B and (B) Chang liver were treated with vehicle $(-)$ or $250 \mathrm{ng} / \mathrm{ml}$ leptin $(+)$ in serum-free media for 30 and 15 min respectively. Following, the protein amounts of phosphorylated forms of JAK2 (p-JAK2), Akt (p-Akt), or ERK1/2 (p-ERK1/2) were detected with western blotting analyses. The same blots were stripped and reprobed with antibodies specific for total proteins of JAK2, Akt, or ERK1/2. The reprobed $\beta$-actin was used as an alternative internal control. Alternative inhibitors $25 \mu \mathrm{M}$ LY294002 (LY) and $20 \mu \mathrm{M}$ PD98059 (PD) for PI3K/Akt and MEK/ERK1/2 respectively, were tested in the similar experiments in Hep3B (C). Data represent three independent experiments. Leptin activates a JAK2-initiated signaling cascade comprising PI3K/Akt and MEK/ERK1/2 in order of occurrence.

concomitantly blocked leptin-induced phosphorylations of both Akt and ERK1/2 (Fig. 5A and B, lane 5). These observations suggest that PI3K/Akt locates upstream from MEK/ERK1/2 within leptin-activated signaling pathway. To ruling out the possibility that results of inhibition experiments were from non-specific effects of wortmannin and U0126, their corresponding inhibitors LY294002 and PD98059 were tested. Like U0126, pre-treatment of PD98059 completely prevented leptininduced phosphorylation of ERK1/2 without reducing leptin induction on the amounts of phosphorylated forms of JAK2 and Akt (Fig. 5C, lane 3). On the other hand, pre-treatment of LY294002, just resembling wortmannin, entirely cancelled leptin induction on phosphorylations of both Akt and ERK1/2, but did not affect induction of phosphorylated JAK2 by leptin (Fig. 5C, 
A

\begin{tabular}{llllll} 
Leptin & - & + & + & + & + \\
\cline { 2 - 6 } Inhibitor & - & - & AG & U0 & Wort \\
Cyclin D1 & & - & & & \\
$\beta$-Actin & & & & &
\end{tabular}

B

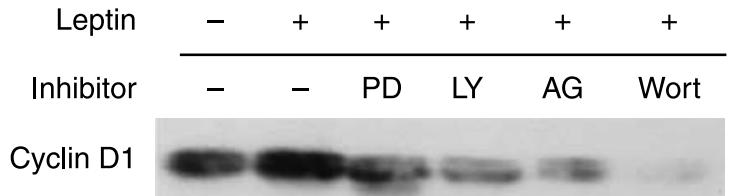

$\beta$-Actin

C

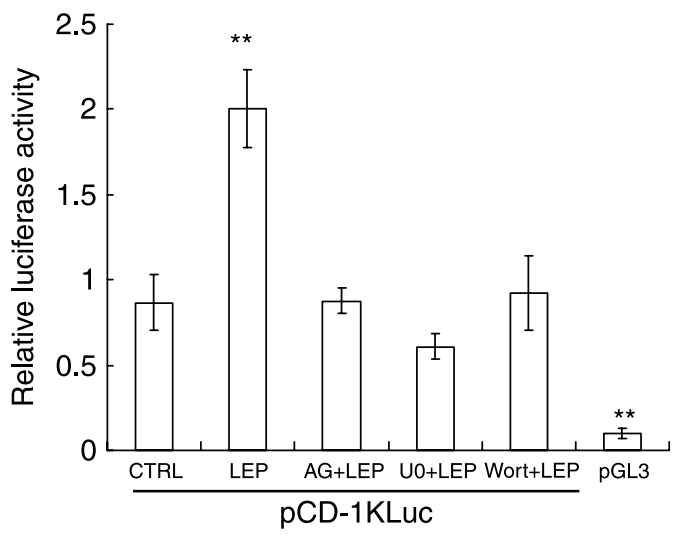

Figure 6 Pharmacological inhibitors of JAK2, PI3K/Akt, and MEK/ERK1/2 prevent hepatic cyclin D1 expression from leptin induction. Hep3B was serum starved for $24 \mathrm{~h}$, and then treated with vehicle (-), $250 \mathrm{ng} / \mathrm{ml}$ leptin (+), $250 \mathrm{ng} / \mathrm{ml}$ leptin together without $(-)$ or with $(+) 40 \mu \mathrm{M}$ AG490 (AG), $250 \mathrm{nM}$ wortmannin (Wort), $10 \mu \mathrm{M}$ U0126 (U0), $25 \mu \mathrm{M}$ LY294002 (LY), or $20 \mu \mathrm{M}$ PD98059 (PD) for $48 \mathrm{~h}$ (A and B). After 48-h treatment, the cell extracts were harvested and subjected to western blotting analysis for detecting cyclin D1 protein amounts using $\beta$-actin as an internal control. To measure leptin effect on cyclin D1 promoter activity, Hep3B, after 24-h serum starvation, was transfected with $\mathrm{pCD}-1 \mathrm{KLuc}$ containing a firefly luciferase gene driven by the $-927 /+39$ fragment of cyclin D1 promoter, or the promoterless parent vector, pGL3Basic (pGL3) as a negative control, together with a CMV promoter-driven renilla luciferase construct as an internal control (C). After $24 \mathrm{~h}$, pGL3Basic-transfected cells (pGL3) were still maintained in serum-free media, but pCD-1KLuc-transfected cells were incubated with serum-free media containing vehicle (CTRL), $250 \mathrm{ng} / \mathrm{ml}$ leptin (LEP), $250 \mathrm{ng} / \mathrm{ml}$ leptin together with $40 \mu \mathrm{M}$ AG490 (AG + LEP), $250 \mathrm{nM}$ wortmannin (Wort + LEP), or $10 \mu \mathrm{M}$ U0126 (U0 + LEP). After 48-h treatment, the transfected cell extracts were harvested and subjected to the dual luminescence reporter gene assay system for detecting their luciferase activities. After normalization of firefly luciferase activities with renilla luciferase activities, the relative luciferase lane 4). According to these constant findings, we propose that leptin probably triggers a JAK2-initiated signaling cascade, comprising PI3K/Akt and MEK/ERK1/2 in the order of crosstalking priority in hepatic cells.

\section{JAK2, PI3K/Akt, and MEK/ERK1/2 mediate leptin- induced cyclin D1-dependent cell cycle progression}

To clarify the role JAK2, PI3K/Akt, and MEK/ERK1/2 play in leptin-accelerated cell cycle progression, we examined the effects of their inhibitors on cyclin D1 expression and cell fate of Hep3B. All specific inhibitors of JAK2 (AG490), PI3K/Akt (wortmannin and LY294002), and MEK/ERK1/2 (U0126 and PD98059) blocked leptin induction on cyclin D1 protein amounts, detected with western blotting analyses (Fig. 6A and B). Similar inhibitions by AG490, wortmannin, and U0126 were observed on the cyclin D1 promoter activity, analyzed by reporter luciferase activity assays of pCD1KLuc-transfected Hep3B (Fig. 6C). These results suggest that activations of JAK2, PI3K/Akt, and MEK/ ERK1/2 perhaps mediate leptin induction on cyclin $D 1$ gene expression of HCC cells.

Subsequently, we would like to know whether the activations of JAK2, PI3K/Akt, and MEK/ERK1/2 are involved in leptin-promoted cell cycle progression. With flow cytometric analyses to monitor the cell cycle profiles of Hep3B, we found that leptin significantly reduced the ratio of G0/G1-phase populations but increased the number of both S- and G2/M-phase cells; however, any one of AG490, wortmannin, and U0126 broke the leptin-controlled acceleration of cell cycle progression (Table 2). Taken together, our findings suggest that the signaling pathways involving activations of JAK, PI3K/Akt, and MEK/ERK1/2 may mediate leptin stimulation to speed up cyclin D1depenedent cell cycle progression in HCC cells.

\section{Leptin inhibits TGF- $\beta 1$-induced apoptosis by down-regulating Bax expression}

After verifying proliferative effect of leptin, we like to examine its anti-apoptotic effect. The MTT assays showed that cell viability of Hep3B was significantly decreased after treatment with TGF- $\beta 1$ (Fig. 7A), an anti-proliferative and apoptogenic factor of many cell

activities calculated from five replicates were graphed with the mean \pm s.D. values. The statistically significant differences compared with the control (CTRL) are noted as ${ }^{\star} P<0.05$, ${ }^{\star \star} P<0.01$, and ${ }^{* \star} P<0.001$. Similar results were observed in three independent experiments. Activations of JAK2, PI3K/Akt, and MEK/ERK1/2 mediate leptin induction on hepatic cyclin D1 expression. 
Table 2 Specific inhibitors of Janus kinase 2, phosphatidylinositol 3-kinase/Akt, and mitogen-activated protein kinase/ extracellular signal-regulated kinase $1 / 2$ prevent the leptin-accelerated hepatic cell cycle progression

\begin{tabular}{lccc}
\hline & $\begin{array}{c}\% \\
\text { G0/G1- } \\
\text { phase }\end{array}$ & $\begin{array}{c}\% \\
\text { S-phase }\end{array}$ & $\begin{array}{c}\% \\
\text { G2/M-phase }\end{array}$ \\
\hline Vehicle & $84.0 \pm 2.2$ & $9.2 \pm 1.2$ & $6.2 \pm 1.6$ \\
Leptin & $71.7 \pm 3.4^{\ddagger}$ & $14.8 \pm 2.6^{\ddagger}$ & $14.0 \pm 1.3^{\ddagger}$ \\
Leptin + AG490 & $87.6 \pm 2.3^{*}$ & $4.7 \pm 2.0^{*}$ & $7.9 \pm 2.2$ \\
Leptin + wortmannin & $82.9 \pm 1.0$ & $11.2 \pm 3.0$ & $6.0 \pm 2.6$ \\
Leptin + U0126 & $80.4 \pm 2.5^{*}$ & $11.5 \pm 1.9$ & $8.1 \pm 2.4$ \\
\hline
\end{tabular}

${ }^{\star} P<0.05,{ }^{\dagger} P<0.01$, and ${ }^{\ddagger} P<0.001$ versus the control (vehicle).

types including HCC (Lamboley et al. 2000, Zhang et al. 2006). The results from western blotting analyses showed that $116 \mathrm{kDa}$ active poly(ADP-ribose) polymerase (PARP) was cleaved into two 89 and $28 \mathrm{kDa}$ fragments by TGF- $\beta 1$ treatment (Fig. 7B; the $28 \mathrm{kDa}$ fragment not shown), indicating that TGF- $\beta 1$ induces Hep3B apoptosis. The TGF- $\beta 1$-induced apoptosis was accompanied with increased expression of Bax, a pro-apoptotic Bcl-2 family protein, in the analyses of western blotting (Fig. 7C). Since TGF- $\beta 1$ did not affect expression of $\mathrm{Bcl}-2$, an anti-apoptotic Bcl-2 family protein, TGF- $\beta 1$ eventually reduced the ratio between anti-apoptotic (Bcl-2) and pro-apoptotic (Bax) Bcl-2 family proteins (Fig. 7C). These results suggest that TGF- $\beta 1$ induces Hep3B apoptosis, at least partly, through up-regulation of pro-apoptotic Bax and resulting reduction of the $\mathrm{Bcl}-2 / \mathrm{Bax}$ ratio. Interestingly, leptin rescued Hep3B from TGF- $\beta 1$-induced cell death (Fig. 7A). Although proliferative effect of leptin may compensate TGF- $\beta 1$-reduced cell viability to some extent, the reduction of TGF- $\beta 1$-induced PARP cleavage by leptin (Fig. 7B) clearly indicates that antiapoptotic effect of leptin, which down-regulated Bax expression and resulted in partial reverse of TGF- $\beta 1$ reduced $\mathrm{Bcl}-2 / \mathrm{Bax}$ ratio (Fig. $7 \mathrm{C}$ ), also contributes to maintain the number of cell population. Comparing with control (vehicle) group, treatment of leptin alone had little basal effects on expressions of Bax, Bcl-2 (Fig. 7D) and cleavage of PARP (Fig. 9A, lanes 1, 7, and 8).

\section{Anti-apoptotic effect of leptin goes through activations of JAK2, PI3K/Akt, and MEK/ERK1/2}

To know what signaling pathway leptin functions through to defend HCC cells against TGF- $\beta 1$-induced apoptosis, we co-treated cells with specific inhibitors of leptin-signaling kinases. As detected by MTT assay, leptin significantly salvaged Hep3B from TGF- $\beta 1$ - induced cell death; moreover, all inhibitors, including AG490 (Fig. 8A), wortmannin (Fig. 8B), and U0126 (Fig. 8C), blocked the leptin rescue. Additionally, we found that leptin dose-dependently antagonized the TGF- $\beta 1$ induction on PARP cleavage and Bax expression (Fig. 9A and B). Any one of AG490, wortmannin, and U0126 restored the leptin-suppressed TGF- $\beta 1$ induction on PARP cleavage and Bax expression (Fig. 9A and B). All treatments had comparable Bcl-2 expression with that of control group (vehicle only; Fig. 9B). Apparently, the signaling pathway involving activations of JAK2, PI3K/Akt, and MEK/ERK1/2 mediates anti-apoptotic effect of leptin against TGF- $\beta 1$-induced HCC apoptosis.

\section{Discussion}

Many studies of liver damages and diseases had implied that obesity and its biomarker leptin may play an important role in cirrhotic HCC progression. In this study, we demonstrate the direct effect of leptin stimulating HCC cell growth. Our evidence show that leptin up-regulates cyclin D1 expression to promote HCC cell proliferation and down-regulates proapoptotic Bax to prevent HCC cells from apoptosis. Combining proliferative and anti-apoptotic effects, leptin potentially functions as a growth factor of HCC cells. While we look at the relevance of obesity and leptin to liver cirrhosis and resulting cirrhotic $\mathrm{HCC}$, the present results remind us to share the same attention on the role of obesity and leptin in noncirrhotic HCC development.

Although it has been known that leptin functions like a growth factor in various types of cancer cells (Somasundar et al. 2004, Garofalo \& Surmacz 2006), the cyclin D1-dependent proliferative effect of leptin is little reported. We verified the leptin stimulation on growth of hepatocytes and HCC cells (Fig. 1B-G), and confirmed the cyclin D1-dependent proliferative effect of leptin on HCC cells by showing that leptin induced cyclin D1 expression (Figs 2 and 6) and concomitantly shifted cell populations from G0/G1-phase to both S- and G2/M-phases (Table 1). The aberrant expression of cyclin D1, which functions as a sensor of growth factors and controls the cell cycle transition from G1- to S-phase, is a hallmark of carcinogenesis (Knudsen et al. 2006). Given that disruption of the regulatory system controlling G1-phase progression is a common event in human hepatocarcinogenesis and cyclin D1 overexpression plays a carcinogenic role in a subset (11-13\%) of HCCs (Hui et al. 1998), our results that leptin stimulated HCC cells to highly express cyclin D1 well document the 

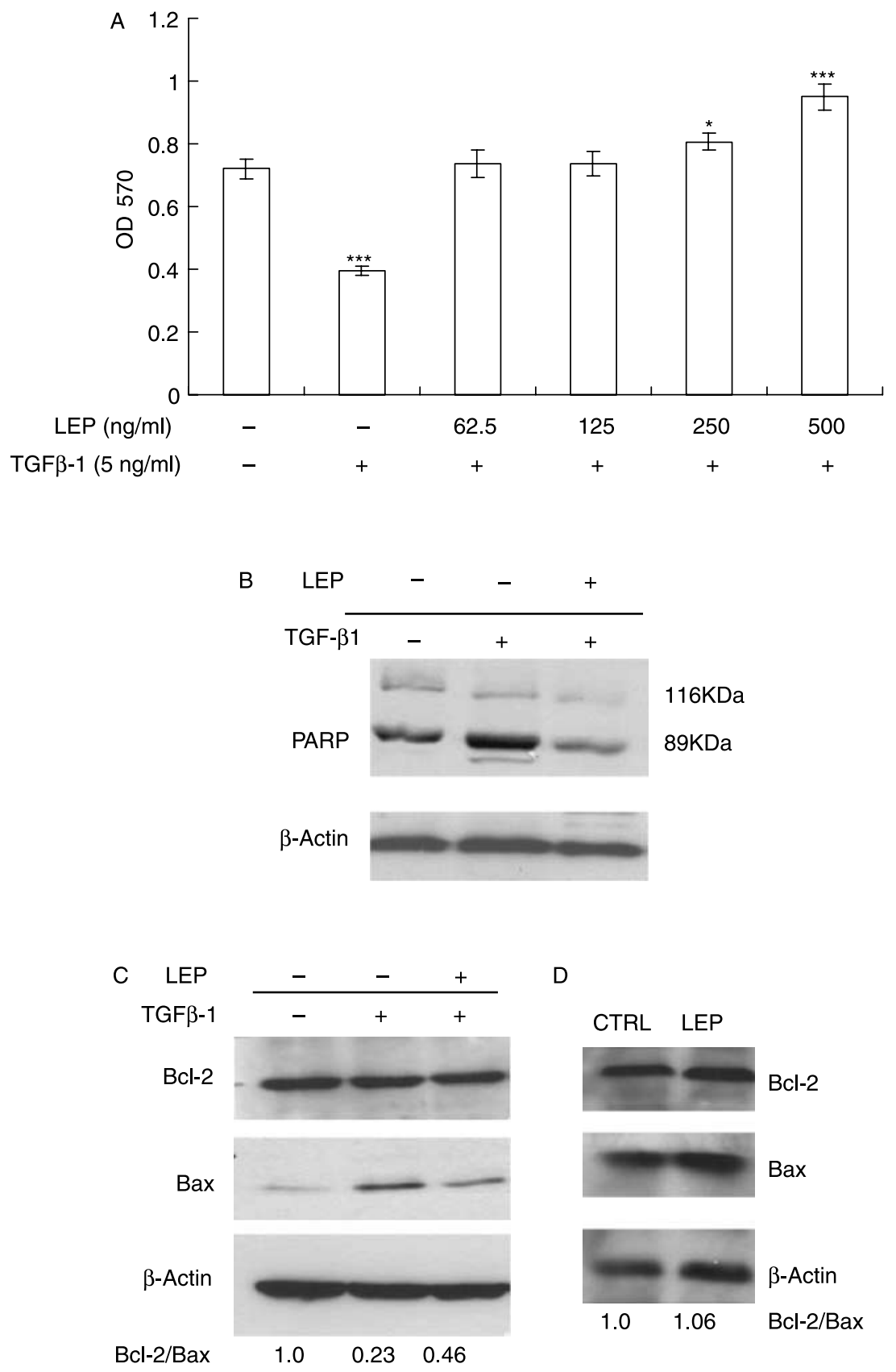

Figure 7 Leptin protects HCC cells from TGF- $\beta 1$-induced apoptosis by down-regulating apoptotic Bax expression. After $24 \mathrm{~h}$, Hep3B cells were seeded in 96-well plates and maintained in serum-free media, cells were incubated without $(-)$ or with $(+) 5 \mathrm{ng} / \mathrm{ml} \mathrm{TGF}-$ $\beta 1$ together without $(-)$ or with $(+)$ indicated concentrations of leptin in serum-free media. After 48-h treatment, their cell viabilities were measured using MTT assay (A). The mean and S.D. values were calculated from 16 replicates. Data represent three independent experiments. The statistically significant differences compared with the control $(-/-)$ are noted as ${ }^{\star} P<0.05,{ }^{\star \star} P<$ 0.01 , and ${ }^{* \star *} P<0.001$. To understand leptin effect on cell apoptosis, the cell lysates of Hep3B cultured in $100 \mathrm{~mm}$ Petri dish and treated without ( - or CTRL) or with (+) $5 \mathrm{ng} / \mathrm{ml} \mathrm{TGF-} \beta 1$ together without ( - or CTRL) or with (+ or LEP) $250 \mathrm{ng} / \mathrm{ml}$ leptin in serumfree media for $48 \mathrm{~h}$ were subjected to western blotting analyses for detecting the cleavage of PARP (B) and the protein amounts of $\mathrm{Bcl}-2$ and $\mathrm{Bax}(\mathrm{C}$ and $\mathrm{D})$ using $\beta$-actin as internal controls. The active PARP $(116 \mathrm{kDa})$ and the larger fragment of cleaved PAPR $(89 \mathrm{kDa})$ are indicated in $(\mathrm{B})$. The ratios between anti-apoptotic $\mathrm{Bcl}-2$ and pro-apoptotic Bax from each treatment are listed in $(\mathrm{C})$ and (D). Leptin protects Hep3B against TGF- $\beta 1$-induced apoptosis by way of down-regulating Bax expression. 

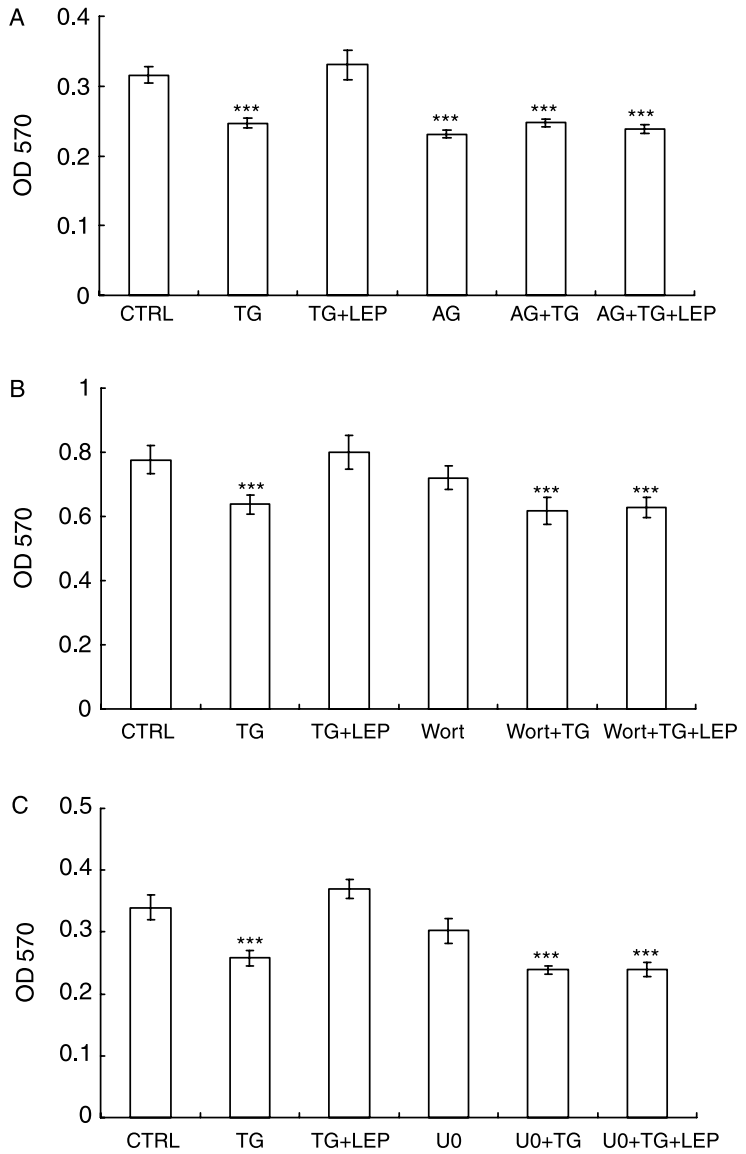

Figure 8 Inhibitors of JAK2, PI3K/Akt, and MEK/ERK1/2 withdraw leptin rescue of TGF- $\beta 1$-induced HCC cell death. After $24 \mathrm{~h}$, Hep3B cells were seeded in 96-well plates and maintained in serum-free media, cells were incubated with vehicle (CTRL), $5 \mathrm{ng} / \mathrm{ml}$ TGF- $\beta 1$ (TG), $40 \mu \mathrm{M}$ AG490 (AG) (A), $250 \mathrm{nM}$ wortmannin (B) or $10 \mu \mathrm{M}$ U0126 (C), or $5 \mathrm{ng} / \mathrm{ml} \mathrm{TGF}-\beta 1$ together with $250 \mathrm{ng} / \mathrm{ml}$ leptin (TG + LEP), $40 \mu \mathrm{M}$ AG490 (AG+ TG) (A), $250 \mathrm{nM}$ wortmannin (Wort +TG) (B) or $10 \mu \mathrm{M}$ U0126 (U0 + TG) (C), or $5 \mathrm{ng} / \mathrm{ml} \mathrm{TGF- \beta 1} \mathrm{combined} \mathrm{with} 250 \mathrm{ng} / \mathrm{ml}$ leptin plus $40 \mu \mathrm{M}$ AG490 (AG + TG + LEP) (A), $250 \mathrm{nM}$ wortmannin (Wort + TG + LEP) (B) or $10 \mu \mathrm{M} \mathrm{U0126} \mathrm{(U0+TG} \mathrm{+}$ LEP) (C) in serum-free media. After 48-h treatment, their cell viabilities were measured with MTT assay. The mean and S.D. values were calculated from 24 replicates. The statistically significant differences compared with the control (CTRL) are

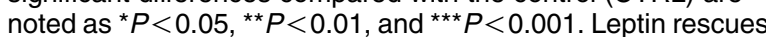
HCC cells from TGF- $\beta 1$-induced apoptosis through activations of JAK2, PI3K/Akt, and MEK/ERK1/2.

potential role of leptin in HCC development. Similar induction of cyclin D1 expression by leptin was observed in human breast cancer cells (Okumura et al. 2002, Chen et al. 2006a) and colon cancer HT-29 cell line (Rouet-Benzineb et al. 2004), as well as primary mouse HSCs (Saxena et al. 2004). In addition, our observations that the $5^{\prime}$-flanking $-927 /+39$ region of cyclin D1 promoter was commonly responsive to the stimulation by leptin, EGF, and serum in HCC cells (Fig. 2B) suggest
A

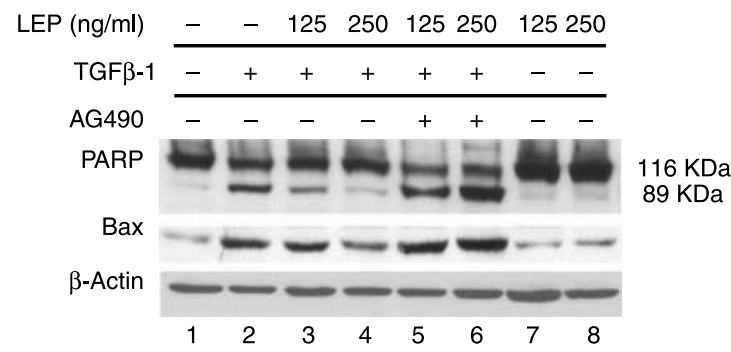

B

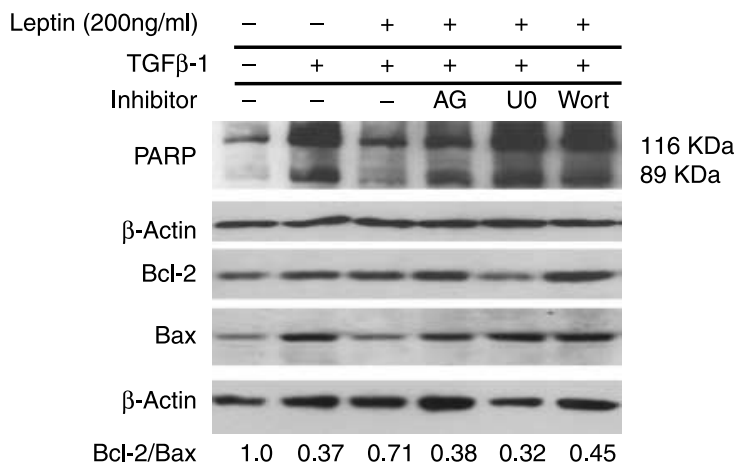

Figure 9 Leptin passes through a JAK2-PI3K/AktMEK/ERK1/2 signaling cascade to partially reverse the TGF$\beta 1$-reduced $\mathrm{Bcl}-2 / \mathrm{Bax}$ ratio and thus prevent $\mathrm{HCC}$ apoptosis. After $24 \mathrm{~h}$, Hep3B cells were seeded in $100 \mathrm{~mm}$ Petri dish and maintained in serum-free media, cells were treated without $(-)$ or with $(+)$ indicated concentrations of leptin, together without $(-)$ or with $(+) 5 \mathrm{ng} / \mathrm{ml} \mathrm{TGF- \beta 1}$ in combination without $(-)$ or with (+) $40 \mu \mathrm{M}$ AG490 (A), $250 \mathrm{nM}$ wortmannin or $10 \mu \mathrm{M}$ U0126 (B) in serum-free media for $48 \mathrm{~h}$. Subsequently, their cell lysates were subjected to western blotting analyses for detecting the cleavage of PARP and the protein amounts of Bcl-2 and Bax using $\beta$-actin as an internal control. The active PARP $(116 \mathrm{kDa})$ together with the larger fragment of cleaved PAPR $(89 \mathrm{kDa})$ and the calculated $\mathrm{Bcl} / \mathrm{Bax}$ ratio from each treatment are indicated. Activations of JAK2, PI3K/Akt, and MEK/ERK1/2 are essential for mediating leptin inhibition on TGF- $\beta 1$-induced Bax expression and resulting Hep3B apoptosis.

that human cyclin D1 promoter activity is, at least partly, driven by interaction of its $5^{\prime}$-flanking 927 bp region, possibly containing multiple cis-elements or a common cis-element, with trans-acting factors activated by distinct growth factors.

TGF- $\beta 1$ is an effective inducer for Hep3B apoptosis evaluated by several apoptotic characteristics like cleavage of PARP (Lamboley et al. 2000). In our experiments, TGF- $\beta 1$ increased pro-apoptotic Bax expression without affecting Bcl-2 expression, leading to reduce the ratio between anti-apoptotic (Bcl-2) and pro-apoptotic (Bax) Bcl-2 family proteins (Figs 7C and 9B). That reduced $\mathrm{Bcl}-2 / \mathrm{Bax}$ ratio facilitates the release of mitochondrial cytochrome $\mathrm{C}$, which subsequently induces cascaded activations of caspases that cleave $116 \mathrm{kDa}$ active PARP into two inactive 89 and 
$28 \mathrm{kDa}$ fragments (Ferrer \& Planas 2003, Harada \& Grant 2003). The cleavage of PARP is one of the irreversible events resulting in programed cell death. Here, for the first time, we observe that leptin protects HCC cells from TGF- $\beta 1$-induced apoptosis by downregulating pro-apoptotic Bax expression and consequentially increasing the $\mathrm{Bcl}-2 / \mathrm{Bax}$ ratio (Figs 7 and 9). By the similar way, leptin also protects human osteoblastic cells (Gordeladze et al. 2002), rat enterocytes (Sukhotnik et al. 2006) and follicular cells (Almog et al. 2001), and bovine oocytes (Boelhauve et al. 2005) against apoptosis.

In comparison with the other five short isoforms of leptin receptors, the role of full-length OBRb in leptin signaling is well studied and recognized as the main signal mediator of leptin. Owing to lack of an intrinsic tyrosine kinase domain, the OBRb binds and activates cytoplasmic kinases, such as JAK2, which continuously initiates the subsequent signal pathways, primarily including STAT3, PI3K/Akt, and MEK/ERK1/2 (Fruhbeck 2006). These signal pathways are also commonly activated by the binding of tyrosine kinase receptors with distinct growth factors to promote proliferation of HCC cells through transactivation of cell cycle regulators like cyclin D1 (Roberts \& Gores 2005). In the leptin-treated Hep3B and Chang liver, we find that leptin induced the phosphorylations of JAK2, Akt, and ERK1/2 (Fig. 3), and either inhibitor specific for JAK2, PI3K/Akt, or MEK/ERK1/2 completely blocked both leptin-induced cyclin D1 expression (Fig. 6) and cell proliferation (Fig. 4; Table 2). Obviously, the proliferative effect of leptin is mediated by activations of JAK2, PI3K/Akt, and MEK/ERK1/2; moreover, the pharmacological inhibition experiments reveal that JAK2 locates prior to PI3K/Akt and MEK/ERK1/2, as the JAK2 inhibitor AG490 also prevented phosphorylations of Akt and ERK1/2 from leptin activation (Fig. 5A and $\mathrm{B}$, lane 3 ).

Activations of both JAK2-linked pathways, PI3K/Akt (Zhao et al. 2002, Sahu 2004, Hsu et al. 2006) and MEK/ERK1/2 (Husain et al. 2001, Pai et al. 2005), by leptin were frequently observed, but few reports showed their signaling crosstalks. A previous study observed that the specific MEK/ERK1/2 inhibitor blocked leptin-induced PI3K activity (Ktori et al. 2003). Dissimilarly, we do not see any effect of MEK/ERK1/2 inhibitors, U0126 and PD98059, on leptin-induced phosphorylation of Akt (Fig. 5A and B, lane 4; Fig. 5C, lane 3), but find that PI3K/Akt inhibitors, wortmannin and LY294002, blocked leptininduced phosphorylation of ERK $1 / 2$ instead (Fig. 5A-C, lane 5; lane 4). As a result, in hepatocytes and HCC cells, PI3K/Akt plausibly plays an upstream mediator of MEK/ERK1/2 during leptin signaling. Taken together, we propose a signaling pathway, connecting JAK2, PI3K/Akt, and MEK/ERK1/2 with time priority, to mediate leptin stimulation on the cyclin D1-dependent proliferation of hepatocytes and HCC cells. Similar activations of JAK2, PI3K/Akt, and MEK/ERK1/2 were involved in leptin effect on proliferation of human cancer cells from breast (Chen et al. 2006a, Frankenberry et al. 2006) and endometrium (Sharma et al. 2006). Additionally, the specific inhibitors stop the behaviors of leptin against TGF- $\beta 1$ induced apoptotic characters (Figs 8 and 9); therefore, we speculate that leptin carries out its anti-apoptotic effect as well as proliferative effect through the same JAK2-PI3K/Akt-MEK/ERK1/2 pathway in early signaling events. In good agreement with our results, leptin suppressed apoptosis of human neuroblastoma cells by down-regulating the apoptotic factors caspase10 and tumor necrosis factor-related apoptosis-inducing ligand (TRAIL) through activations of JAK2, PI3K/Akt, and MEK/ERK1/2 (Russo et al. 2004).

In certain cases, leptin effects might pass through complicated signaling crosstalks. Like human colon HT-29 cancer cells, the activations of JAK2, PI3K/Akt, and JNK were required for mediating both proliferative and anti-apoptotic effects of leptin; wherein activated JAK2 separately activated PI3K/Akt and STAT3 but not c-Jun N-terminal kinase (JNK), and JNK increased activating protein-1 (AP-1) transcriptional activity when activated (Ogunwobi \& Beales 2007). In that case, the involved signaling pathways, such as JAK2-STAT3, JAK2-PI3K/Akt, and JNK-AP-1, function as paralleled linkages instead of series connection. Although we do not forget about the possible roles of the other pathways in leptin effects and cannot rule out the possibility that pleiotropic effects of leptin could be a consequence of the entangled relationships among leptin signaling pathways, the essential role of the JAK2-PI3K/AktMEK/ERK1/2 linkage in the early signaling events of leptin effects was certainly verified in the studied HCC cells. This convinced hierarchy of leptin signaling pathway in fact provides sufficient advantage for making focus strategies to fight obesityrelated or/and cirrhosis-associated liver cancer.

Contrary to our results, the anti-tumor effect of leptin on HCC in vivo and in vitro has currently been reported. Compared with the control groups, the leptintreated groups of Hep3B-transplanted mice had reduced the tumor size, improved the survival rate, and significantly increased the peripheral natural killer cells (Elinav et al. 2006). We address the possibility whether the reported anti-tumor effect actually resulted 


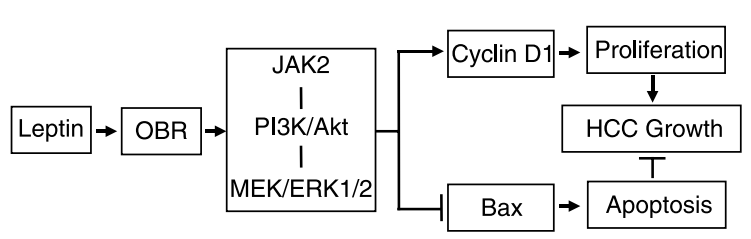

Figure 10 A hypothetic mode underlying somatotropic effect of leptin on HCC cells. HCC cells receive leptin signaling possibly through OBRb and/or OBRa. Intracellularly, leptin-liganded OBR activates its associated kinase, JAK2. Afterwards, the active JAK2 induces activations of PI3K/Akt that subsequently activates MEK/ERK1/2. In consequence, the JAK2-initiated signaling cascade mediates leptin effect to up-regulate cyclin D1 expression and down-regulate Bax expression. Eventually, up-regulated cyclin D1 speeds up cell cycle progression to stimulate cell proliferation, and down-regulated Bax prevents cells from apoptosis. Combining both proliferative and antiapoptotic effects, leptin potentially functions as a growth factor to stimulate HCC cell growth.

from the natural killer cell-mediated immune defense of mouse host to reject human Hep3B xenograft, rather than an inhibitory effect of leptin on hepatocellular carcinogenesis. However, an in vitro inhibition of Hep3B growth by leptin was simultaneously displayed in that paper. The reason causing distinct results from ours is unclear. Nevertheless, we have identified the proliferative effect of leptin in two HCC (HepG2 and Hep3B) and one non-malignant Chang liver cell lines, as well as anti-apoptotic effect of leptin in Hep3B. Our results from pharmacological inhibition experiments consistently demonstrate that leptin promotes hepatocytic cell cycle progression by up-regulation of cyclin D1 and reduces programed cell death by downregulation of Bax through a JAK2-PI3K/Akt-MEK/ ERK1/2 cascaded pathway (Fig. 10). Combining both proliferative and anti-apoptotic effects, it is convincing that leptin potentially functions as a growth factor of HCC cells. Further studies are expected to understand the reasons for the conflicting observations and the reality of leptin function on liver tumorigenesis.

\section{Acknowledgements}

This work was supported by the National Taiwan University and the Mackay Memorial Hospital, and by the grants NSC 95-2313-B-002-061-MY3 to I-C Guo, NSC 92-2314-B-195-020 and NSC 93-2314-B-195026 to C-L L, and NSC 91-2320-B-002-160 to K-J C from the National Science Council, and DOH95TD-HF-111-003(1/3) to I-C Guo from the Department of Health, Executive Yuan, Republic of China. C C, YC C, C-L L, T-P L, K-J C, and I-C G declare that there is no conflict of interest that would prejudice the impartiality of this scientific work.

\section{References}

Almog B, Gold R, Tajima K, Dantes A, Salim K, Rubinstein M, Barkan D, Homburg R, Lessing JB, Nevo N et al. 2001 Leptin attenuates follicular apoptosis and accelerates the onset of puberty in immature rats. Molecular and Cellular Endocrinology 183 179-191.

Boelhauve M, Sinowatz F, Wolf E \& Paula-Lopes FF 2005 Maturation of bovine oocytes in the presence of leptin improves development and reduces apoptosis of in vitroproduced blastocysts. Biology of Reproduction $\mathbf{7 3}$ 737-744.

Briscoe CP, Hanif S, Arch JR \& Tadayyon M 2001 Leptin receptor long-form signalling in a human liver cell line. Cytokine 14 225-229.

Bugianesi E, Leone N, Vanni E, Marchesini G, Brunello F, Carucci P, Musso A, De Paolis P, Capussotti L, Salizzoni $\mathrm{M}$ et al. 2002 Expanding the natural history of nonalcoholic steatohepatitis: from cryptogenic cirrhosis to hepatocellular carcinoma. Gastroenterology 123 134-140.

Calle EE, Rodriguez C, Walker-Thurmond K \& Thun MJ 2003 Overweight, obesity, and mortality from cancer in a prospectively studied cohort of US adults. New England Journal of Medicine 348 1625-1638.

Chen C, Chang YC, Liu CL, Chang KJ \& Guo IC $2006 a$ Leptin-induced growth of human ZR-75-1 breast cancer cells is associated with up-regulation of cyclin D1 and c-Myc and down-regulation of tumor suppressor p53 and p21(WAF1/CIP1). Breast Cancer Research and Treatment 98 121-132.

Chen K, Li F, Li J, Cai H, Strom S, Bisello A, Kelley DE, Friedman-Einat M, Skibinski GA, McCrory MA et al. $2006 b$ Induction of leptin resistance through direct interaction of C-reactive protein with leptin. Nature Medicine 12 425-432.

Cohen B, Novick D \& Rubinstein M 1996 Modulation of insulin activities by leptin. Science 274 1185-1188.

Ding X, Saxena NK, Lin S, Xu A, Srinivasan S \& Anania FA 2005 The roles of leptin and adiponectin: a novel paradigm in adipocytokine regulation of liver fibrosis and stellate cell biology. American Journal of Pathology 166 1655-1669.

Dyer Z, Peltekian K \& van Zanten SV 2005 Review article: the changing epidemiology of hepatocellular carcinoma in Canada. Alimentary Pharmacology and Therapeutics 22 17-22.

Elinav E, Abd-Elnabi A, Pappo O, Bernstein I, Klein A, Engelhardt D, Rabbani E \& Ilan Y 2006 Suppression of hepatocellular carcinoma growth in mice via leptin, is associated with inhibition of tumor cell growth and natural killer cell activation. Journal of Hepatology 44 529-536.

Ferrer I \& Planas AM 2003 Signaling of cell death and cell survival following focal cerebral ischemia: life and death struggle in the penumbra. Journal of Neuropathology and Experimental Neurology 62 329-339. 
Frankenberry KA, Skinner H, Somasundar P, McFadden DW \& Vona-Davis LC 2006 Leptin receptor expression and cell signaling in breast cancer. International Journal of Oncology 28 985-993.

Fruhbeck G 2006 Intracellular signalling pathways activated by leptin. Biochemical Journal 393 7-20.

van Gaal LF, Wauters MA, Mertens IL, Considine RV \& De Leeuw IH 1999 Clinical endocrinology of human leptin. International Journal of Obesity and Related Metabolic Disorders 23 29-36.

Garofalo C \& Surmacz E 2006 Leptin and cancer. Journal of Cellular Physiology 207 12-22.

Gonzalez L, Blanc JF, Sa Cunha A, Rullier A, Saric J, Le Bail B, Balabaud C \& Bioulac-Sage P 2004 Obesity as a risk factor for hepatocellular carcinoma in a noncirrhotic patient. Seminars in Liver Disease 24 415-419.

Gordeladze JO, Drevon CA, Syversen U \& Reseland JE 2002 Leptin stimulates human osteoblastic cell proliferation, de novo collagen synthesis, and mineralization: impact on differentiation markers, apoptosis, and osteoclastic signaling. Journal of Cellular Biochemistry 85 825-836.

Guo IC, Wu LS, Lin JH \& Chung BC 2001 Differential inhibition of progesterone synthesis in bovine luteal cells by estrogens and androgens. Life Sciences 68 1851-1865.

Harada H \& Grant S 2003 Apoptosis regulators. Reviews in Clinical and Experimental Hematology 7 117-138.

Hsu HT, Chang YC, Chiu YN, Liu CL, Chang KJ \& Guo IC 2006 Leptin interferes with adrenocorticotropin $/ 3^{\prime}, 5^{\prime}$ cyclic adenosine monophosphate (cAMP) signaling, possibly through a Janus kinase 2-phosphatidylinositol 3-kinase/Akt-phosphodiesterase 3-cAMP pathway, to down-regulate cholesterol side-chain cleavage cytochrome P450 enzyme in human adrenocortical NCI-H295 cell line. Journal of Clinical Endocrinology and Metabolism 91 2761-2769.

Hui AM, Makuuchi M \& Li X 1998 Cell cycle regulators and human hepatocarcinogenesis. Hepatogastroenterology 45 1635-1642.

Husain SS, Szabo IL, Pai R, Soreghan B, Jones MK \& Tarnawski AS 2001 MAPK (ERK2) kinase - a key target for NSAIDs-induced inhibition of gastric cancer cell proliferation and growth. Life Sciences 69 3045-3054.

Jackson AA 2005 Integrating the ideas of life course across cellular, individual, and population levels in cancer causation. Journal of Nutrition 135 2927S-2933S.

Knudsen KE, Diehl JA, Haiman CA \& Knudsen ES 2006 Cyclin D1: polymorphism, aberrant splicing and cancer risk. Oncogene 25 1620-1628.

Ktori C, Shepherd PR \& O'Rourke L 2003 TNF-alpha and leptin activate the alpha-isoform of class II phosphoinositide 3-kinase. Biochemical and Biophysical Research Communications 306 139-143.

Lamboley C, Bringuier AF \& Feldmann G 2000 Induction of apoptosis in normal cultured rat hepatocytes and in Hep3B, a human hepatoma cell line. Cell Biology and Toxicology 16 185-200.
Liu ZJ, Endoh A, Li R \& Ohzeki T 2004 Effects of leptin and dexamethasone on long and short leptin receptor mRNA. Pediatrics International 46 561-564.

Marrero JA, Fontana RJ, Fu S, Conjeevaram HS, Su GL \& Lok AS 2005 Alcohol, tobacco and obesity are synergistic risk factors for hepatocellular carcinoma. Journal of Hepatology 42 218-224.

Menu E, Kooijman R, van Valckenborgh E, Asosingh K, Bakkus M, van Camp B \& Vanderkerken K 2004 Specific roles for the PI3K and the MEK-ERK pathway in IGF-1-stimulated chemotaxis, VEGF secretion and proliferation of multiple myeloma cells: study in the 5T33MM model. British Journal of Cancer 90 1076-1083.

Ogunwobi OO \& Beales IL 2007 The anti-apoptotic and growth stimulatory actions of leptin in human colon cancer cells involves activation of JNK mitogen activated protein kinase, JAK2 and PI3 kinase/Akt. International Journal of Colorectal Disease 22 401-409.

Okumura M, Yamamoto M, Sakuma H, Kojima T, Maruyama T, Jamali M, Cooper DR \& Yasuda K 2002 Leptin and high glucose stimulate cell proliferation in MCF-7 human breast cancer cells: reciprocal involvement of PKC-alpha and PPAR expression. Biochimica et Biophysica Acta 1592 107-116.

Pai R, Lin C, Tran T \& Tarnawski A 2005 Leptin activates STAT and ERK2 pathways and induces gastric cancer cell proliferation. Biochemical and Biophysical Research Communications 331 984-992.

Regimbeau JM, Colombat M, Mognol P, Durand F, Abdalla E, Degott C, Degos F, Farges O \& Belghiti J 2004 Obesity and diabetes as a risk factor for hepatocellular carcinoma. Liver Transplantation 10 S69-S73.

Roberts LR \& Gores GJ 2005 Hepatocellular carcinoma: molecular pathways and new therapeutic targets. Seminars in Liver Disease 25 212-225.

Rouet-Benzineb P, Aparicio T, Guilmeau S, Pouzet C, Descatoire V, Buyse M \& Bado A 2004 Leptin counteracts sodium butyrate-induced apoptosis in human colon cancer HT-29 cells via NF- $\kappa \mathrm{B}$ signaling. Journal of Biological Chemistry 279 16495-16502.

Russo VC, Metaxas S, Kobayashi K, Harris M \& Werther GA 2004 Antiapoptotic effects of leptin in human neuroblastoma cells. Endocrinology 145 4103-4112.

Sahu A 2004 Minireview: a hypothalamic role in energy balance with special emphasis on leptin. Endocrinology 145 2613-2620.

Saxena NK, Titus MA, Ding X, Floyd J, Srinivasan S, Sitaraman SV \& Anania FA 2004 Leptin as a novel profibrogenic cytokine in hepatic stellate cells: mitogenesis and inhibition of apoptosis mediated by extracellular regulated kinase (Erk) and Akt phosphorylation. FASEB Journal 18 1612-1614.

Sharma D, Saxena NK, Vertino PM \& Anania FA 2006 Leptin promotes the proliferative response and invasiveness in 
human endometrial cancer cells by activating multiple signal-transduction pathways. Endocrine-Related Cancer 13 629-640.

Somasundar P, McFadden DW, Hileman SM \& Vona-Davis L 2004 Leptin is a growth factor in cancer. Journal of Surgical Research 116 337-349.

Sukhotnik I, Vadasz Z, Coran AG, Lurie M, Shiloni E, Hatoum OA \& Mogilner JG 2006 Effect of leptin on intestinal re-growth following massive small bowel resection in rat. Pediatric Surgery International 22 9-15.

Uauy R \& Solomons N 2005 Diet, nutrition, and the lifecourse approach to cancer prevention. Journal of Nutrition 135 2934S-2945S.

Wang Y, Kuropatwinski KK, White DW, Hawley TS, Hawley RG, Tartaglia LA \& Baumann H 1997 Leptin receptor action in hepatic cells. Journal of Biological Chemistry 272 16216-16223.
Wang XJ, Yuan SL, Lu Q, Lu YR, Zhang J, Liu Y \& Wang WD 2004 Potential involvement of leptin in carcinogenesis of hepatocellular carcinoma. World Journal of Gastroenterology 10 2478-2481.

Zhang H, Ozaki I, Mizuta T, Hamajima H, Yasutake T, Eguchi Y, Ideguchi H, Yamamoto K \& Matsuhashi S 2006 Involvement of programmed cell death 4 in transforming growth factor-beta1-induced apoptosis in human hepatocellular carcinoma. Oncogene 25 6102-6112.

Zhao AZ, Shinohara MM, Huang D, Shimizu M, EldarFinkelman H, Krebs EG, Beavo JA \& Bornfeldt KE 2000 Leptin induces insulin-like signaling that antagonizes cAMP elevation by glucagon in hepatocytes. Journal of Biological Chemistry 275 11348-11354.

Zhao AZ, Huan JN, Gupta S, Pal R \& Sahu A 2002 A phosphatidylinositol 3-kinase phosphodiesterase 3B-cyclic AMP pathway in hypothalamic action of leptin on feeding. Nature Neuroscience 5 727-728. 